\title{
A SWOT Based Study for the Improvement of Bangladeshi RMG Industry
}

\author{
Ayub Nabi Khan*1, Eanamul Haque Nizam $^{1}$ and Tanjibul Hasan Sajib ${ }^{2}$ \\ ${ }^{1}$ BGMEA University of Fashion and Technology, Bangladesh \\ ${ }^{2}$ Department of Fashion Design, BGMEA University of Fashion and Technology, Bangladesh
}

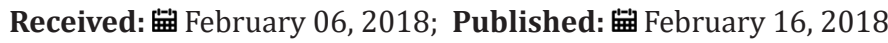

*Corresponding author: Ayub Nabi Khan, BGMEA University of Fashion and Technology, Uattra, Dhaka, Bangladesh, Email: provc@buft.edu.bd

\begin{abstract}
Bangladeshi RMG industry is the main business focus for most of the world because of low wages labour, low CM cost etc. To increase the productivity rate lean is the recent topic for the industry owner. SWOT method is one of them. SWOT Analysis of Garment industry in Bangladesh simply means analyzing the Strength, Weaknesses, Opportunities, and Threats of the garment industry in Bangladesh. From this, we can know the areas where the Bangladeshi Industry is strong and where he has to improve. In this research, the author has prepared a questionnaire and made a survey of it. This questionnaire was filled by various garment industries in Bangladesh. This questionnaire made the author to compare the various aspects of the size of units, lead-time, productivity and CMT charges. Charts were prepared from the surveys and results were obtained from it. By this project, author promotes the details obtained to an entrepreneur in various other places in Bangladesh so that they can start up garment industry in near future.
\end{abstract}

Keywords: RMG; SWOT; Survey; Production; Productivity

\section{Introduction}

SWOT is an acronym which contains four logical analytical words for any kinds of analysis. These are Strength, Weakness, Opportunity, and Threat. This is such a subjective assessment that can be applied to a man, industry, business, place and so on. From the view of RMG industries, it represents a framework for analyzing a company's strengths and weaknesses, and the opportunities and threats it faces in the way to success and one of the inevitable things for a labor-intensive productive industry. The objectives of the firm or industry should be determined after the SWOT analysis has been performed by V. Rameshbabu [1] who allows the organization to achieve the goals or objectives.

a) Strengths refer to the areas of high importance which provide a business or project significant advantages over others.

b) Weaknesses refer to the characteristics or the areas which provide disadvantages and require immediate actions.

c) Opportunities are the elements those should be further implemented and exploited to achieve the desired performance.

d) Threats refer to the elements in the environment that could cause trouble for the business or project.
SWOT analysis aims to identify the key internal and external factors considered as important towards achieving an objective. These factors come from within a company's unique value chain. Internal factors - the strengths and weaknesses internal to the organization [2]. External factors- the opportunities and threats presented by the environment external to the organization. The SWOT analysis provides information that is helpful in matching the firm's resources and capabilities to the competitive environment in which it operates [3].

\section{Literature Review}

The readymade garment is a success story for Bangladesh. The industry started in the late 1970s, expanded heavily in the 1980s and boomed in the 1990s. The quick expansion of the industry was possible because of the following unique nature of the industry.

a) The technology is less complicated (easy to transfer)

b) Types of machinery are cheap and easy to operate (sewing machines)

c) A large female labor force that is easy to train is readily available 
Besides the low cost of labor, one of the major factors behind the success of RMG is the availability of offshore financing for world-priced inputs through the back-to-back letter of credit (L/C) under the special bonded warehouse scheme. Presence of foreign buyers is also a major factor that introduces the system of international subcontracting. Foreign buying houses not only bring the international market to the doorstep of local entrepreneurs, they also ensure the availability of essential inputs such as imported fabrics and accessories for the industry. They also did the greatest favor for the RMG industry of Bangladesh by bringing the latest designs and by monitoring output quality. These measures especially enabled inexperienced garments entrepreneurs to establish a strong foothold during the 1980s [4-6].

\section{Contribution of the Garments Industry of Bangladesh}

From the website, the author got this information. Although suffering from image crisis after the GSP withdrawal from USA, Bangladesh registered remarkable export growth in the just- concluding fiscal year. RMG export grew $12.71 \%$ to 21.5 billion USD and total textiles export including RMG rose to 23.7 billion USD which is $11.24 \%$ higher than the previous financial year (Table 1). Export Promotion Bureau, EPB of Bangladesh has set an ambitious export target for the financial year 2013-14 that is 30.5 billion USD, $12.85 \%$ higher than previous year's export 27.02 billion USD. Though the country could not achieve the last year target, this time also the country want to chase a big target. But the year has been started with a great uplift at its first month. Bangladesh exported textile and clothing (T\&C) products worth of 2696.4 million USD in the month of July, 13 which was 2538.8 million USD previous month and 2311.2 million USD in the same month of the previous year. In fact, exports of the country's clothing products witnessed a robust growth of more than 26 percent in July 2013, amid clothing manufacturers' apprehension that their shipment orders might fall following the tragic Rana Plaza incidents and the image crisis that all were talking about of late aroused from the USA GSP issues $[7,8]$.

Table 1: Comparative statement on export of RMG and total export of Bangladesh [7].

\begin{tabular}{|c|c|c|c|}
\hline \multicolumn{4}{|c|}{ Comparative Statement on Export of Rmg and Total Export of Bangladesh } \\
\hline Year & Export Of Rmg (In Million Us \$) & Total Export Of Bangladesh (In Million Us \$) & \% Of Rmg's To Total Export \\
\hline $1983-84$ & 31.57 & 811.00 & 3.89 \\
\hline $1984-85$ & 116.2 & 934.43 & 12.44 \\
\hline $1985-86$ & 131.48 & 819.21 & 16.05 \\
\hline $1986-87$ & 298.67 & 1076.61 & 27.74 \\
\hline $1987-88$ & 433.92 & 1231.2 & 35.24 \\
\hline 1988-89 & 471.09 & 1291.56 & 36.47 \\
\hline $1989-90$ & 624.16 & 1923.70 & 32.45 \\
\hline 1990-91 & 866.82 & 1717.55 & 50.47 \\
\hline 1991-92 & 1182.57 & 1993.90 & 59.31 \\
\hline $1992-93$ & 1445.02 & 2382.89 & 60.64 \\
\hline 1993-94 & 1555.79 & 2533.90 & 61.40 \\
\hline 1994-95 & 2228.35 & 3472.56 & 64.17 \\
\hline $1995-96$ & 2547.13 & 3882.42 & 65.61 \\
\hline $1996-97$ & 3001.25 & 4418.28 & 67.93 \\
\hline 1997-98 & 3781.94 & 5161.20 & 73.28 \\
\hline 1998-99 & 4019.98 & 5312.86 & 75.67 \\
\hline 1999-00 & 4349.41 & 5752.20 & 75.61 \\
\hline 2000-01 & 4859.83 & 6467.30 & 75.14 \\
\hline 2001-02 & 4583.75 & 5986.09 & 76.57 \\
\hline $2002-03$ & 4912.09 & 6548.44 & 75.01 \\
\hline 2003-04 & 5686.09 & 7602.99 & 74.79 \\
\hline 2004-05 & 6417.67 & 8654.52 & 74.15 \\
\hline 2005-06 & 7900.80 & 10526.16 & 75.06 \\
\hline 2006-07 & 9211.23 & 12177.86 & 75.64 \\
\hline 2007-08 & 10699.80 & 14110.80 & 75.83 \\
\hline 2008-09 & 12347.77 & 15565.19 & 79.33 \\
\hline $2009-10$ & 12496.72 & 16204.65 & 77.12 \\
\hline
\end{tabular}




\begin{tabular}{|l|l|l|l|}
\hline $2010-11$ & 17914.46 & 22924.38 & 78.15 \\
\hline $2011-12$ & 19089.69 & 24287.66 & 78.60 \\
\hline $2012-13$ & 21515.73 & 27018.26 & 79.61 \\
\hline $2013-14$ & 24491.88 & 30176.80 & 81.16 \\
\hline $2014-15$ & 25491.40 & 31208.94 & 81.68 \\
\hline
\end{tabular}

\section{Material and Method}

Material: Four Garments industry has used to conduct this survey. From every industry, top-level management has used to collect the data. Total 20 participants has used from four garments industry.

Method: After conducting the survey process the author make documentation. After collecting their view the author tries to find out the common problem from their view of results. After that, the author suggests SWOT for existing industry.

\section{Results and Discussion}

\section{Survey summary}

Participants: From different industry of 20 top label management was recruited; from the sample 10 (50 percent) participated in the survey and one of the focus group interviews.
A total of three sessions were conducted over four weeks. (Table 2) presents descriptive statistics of the sample. About of the participants were male (20 members). According to this questionnaire, here the author presented one survey report for a clear idea as an example of this part.

Table 2: Descriptive Statistics of Sample Characteristics.

\begin{tabular}{|c|c|c|}
\hline & 1 & \% \\
\hline Gender & $(\mathbf{n = 2 0 )}$ & \\
\hline Male & 20 & 100 \\
\hline Ethnicity & & \\
\hline Industry-01 & 5 & 25 \\
\hline Industry-02 & 5 & 25 \\
\hline Industry-03 & 5 & 25 \\
\hline Industry-04 & 5 & 25 \\
\hline
\end{tabular}

\section{Overall SWOT Satisfaction}

Table 3: Frequency of Ratings of Participants' SWOT Satisfaction in General.

\begin{tabular}{|c|c|c|c|c|c|c|}
\hline & Overall fit satisfaction & 1 & 2 & 3 & 4 & Total \\
\hline 1 & Overall, the experience that Total Strength of industry satisfies. & 3 & 6 & 6 & 5 & 20 \\
\hline 2 & Overall, I am depressed with weakness of my industry & 4 & 1 & 7 & 8 & 20 \\
\hline 3 & Overall, I am unsatisfied with Opportunity of this industry & 7 & 7 & 3 & 3 & 20 \\
\hline 4 & Overall, in working here so much threat presence here & 9 & 1 & 9 & 1 & 20 \\
\hline
\end{tabular}

Reliability of items measuring overall apparel fit satisfaction was assessed using Cronbach's alpha coefficient. As shown in (Table 3), the Cronbach's alpha value for the four items was .912; this indicates a high internal consistency for this factor $[8,9]$. Most of the participant experience was positive and negative. Most of the participant agrees about their strength, weakness, opportunity and also threats. They also agree it is important to factor improve to total productivity of the industry (Table 4). Because there were a comparable number of answers from the total number of the industry of Bangladesh, the difference in fit satisfaction responses across nationalities was examined. There were no significant differences in mean scores of overall SWOT satisfaction between Different industries. The distribution of students according to class standing was fairly equivalent.

Table 4: Results of Independent t-test for Mean Scores of Overall SWOT Satisfaction for Individual industry.

\begin{tabular}{|c|c|c|c|c|c|}
\hline & \multicolumn{2}{|c|}{ Origin } & \multirow[b]{2}{*}{$\mathbf{t}$} & \multirow[b]{2}{*}{ df } & \multirow[b]{2}{*}{$\mathbf{p}$} \\
\hline & $50 \%$ Industry & $50 \%$ Industry & & & \\
\hline Means scores of overall SWOT satisfaction in general & 4.78 & 4.55 & -.18 & 40 & .25 \\
\hline Total & 4.66 & & & & \\
\hline
\end{tabular}

\section{Problem and solutions}

SWOT Analyzing is a very useful technique to identify a company`s Strengths, Weakness, Opportunities, and Threats. SWOT analysis was done in five industries to find out the obstacles of our productivity improvement in RMG sector. One structured questionnaire was also used to conduct a survey of 200 people including Line Supervisors, operators, helpers, IE engineers etc. in different sections of RMG sectors. The threats and problems that hamper productivity are as follows $[10,11]$ : a) Lack of proper training facilities.

b) Lack of regular workers in RMG sector.

c) Lack of dignity in society.

d) Lack of skilled workers.

e) Excessive pressure in some cases.

f) Lack of motivation. 
g) Lack of active baby day-care facilities.

h) Lower salary standard and less satisfaction of the workers.

i) Interrupted utility supply.

j) Improper facility layout. k) No or improper IE section.

l) Lack of human-friendly working condition like ventilation, lighting, proper washroom facilities, odor-free environment etc.

\section{Suggestion}

Table 5

Table 5: SWOT analysis for productivity improvement in RMG industries.

\begin{tabular}{|c|c|}
\hline Strengths (S) & Weaknesses (W) \\
\hline $\begin{array}{c}\varnothing \text { Low-cost power generation by using gas as fuel. } \\
\qquad \text { Cheap labor force } \\
\varnothing \text { Availability and flexibility of raw materials. }\end{array}$ & $\begin{array}{c}\varnothing \text { Lack of investment. } \\
\varnothing \text { Lack of training opportunities. } \\
\varnothing \text { Lack of skilled manpower. } \\
\varnothing \text { Lack of quality management } \\
\varnothing \text { Excessive defects and more re-work. } \\
\varnothing \text { More waiting time and too many bottlenecks. } \\
\varnothing \text { Lack of engineering. } \\
\varnothing \text { More production time. } \\
\varnothing \text { Imbalanced workload distribution } \\
\varnothing \text { Long changeover time. } \\
\varnothing \text { Purchasing of wrong materials. } \\
\varnothing \text { Lack of supervision. } \\
\varnothing \text { Poor salary structure of workers. } \\
\varnothing \text { Lack of worker's motivation. } \\
\varnothing \text { Lack of incentive scheme. } \\
\varnothing \text { Poor working conditions. } \\
\varnothing \text { Lack of lighting and ventilation facility } \\
\varnothing \text { No or improper IE dept. } \\
\varnothing \text { Lack of new technologies and layout. }\end{array}$ \\
\hline Threats (T) & Opportunities (0) \\
\hline $\begin{array}{l}\varnothing \text { Rapid technological growth from outside. } \\
\varnothing \text { Competition with other existing and upcoming global market. } \\
\varnothing \text { Political imbalance. } \\
\varnothing \text { Labor unrest. } \\
\varnothing \text { Interrupted utility supply. } \\
\varnothing \text { Infrastructural bottleneck. }\end{array}$ & $\begin{array}{c}\varnothing \text { Implementing the new methods. } \\
\varnothing \text { Increase of customer relation. } \\
\varnothing \text { More production orders from customers. } \\
\varnothing \text { Increase of business growth in global market especially in USA, Canada, } \\
\text { and Australia and EU countries. } \\
\varnothing \text { Export opportunity in Japan and CIS countries. } \\
\varnothing \text { Increase of profit margin. }\end{array}$ \\
\hline
\end{tabular}

\section{Efficiency\% Comparison}

Before efficiency of the factory (Before Implementation) (January 2017)

Table 6

Table 6: Before implementation of SWOT Suggestion Efficienсу\%.

\begin{tabular}{|c|c|}
\hline Factory & Efficiency \% \\
\hline Factory-01 & 72.86 \\
\hline Factory-02 & 80.00 \\
\hline Factory-03 & 79.66 \\
\hline Factory-04 & 75.34 \\
\hline
\end{tabular}

After efficiency of the factory (Before Implementation) (February 2017)

Table 7

Table 7: After implementation of SWOT Suggestion Efficiency $\%$.

\begin{tabular}{|c|c|}
\hline Factory & Efficiency \% \\
\hline Factory-01 & 78.00 \\
\hline Factory-02 & 82.77 \\
\hline Factory-03 & 80.34 \\
\hline Factory-04 & 76.88 \\
\hline
\end{tabular}




\section{Conclusion}

No hurdles could resist Bangladesh achieving a modest growth in the first six months of the financial year 2013-2014. The country has registered $19.55 \%$ growth in knitwear export and $20.37 \%$ growth in woven wear export despite so many political troubles. Amid great internal tension \& month-long blockade, the sector could keep their momentum going [12]. Countries export growth in July to December hence now comes with a great inspiration for the rest of the year to achieve even more. But such a well-built sector could not really grow as the sector anticipated due to many reasons- most of which are not abnormal for developing countries. Huge infrastructure deficiency, political instabilities, high bank interest, frequent labor insurgency, unexpected accidents; $[13,14]$ Bangladeshi RMG \& textile sector is coping up everything very well. Now the country is to face another big threat from the two big subcontinent countries due to the extra leverages they are gaining. Bangladesh should penetrate into new markets, diversify into new items, and relocate into new territories. If these measures are not taken in time, as Spinanger concludes, "The rapid growth rates that Bangladesh exhibited in world trade will be a thing of the past"[15].

\section{References}

1. Rameshbabu V (2012) SWOT Analysis of Garment industry in Salem, USA.

2. Mohiuddin Shuvo (2015) Productivity of RMG Industry of Bangladesh Graduation thesis p. 32-43.
3. http://en.wikipedia.org/wiki/SWOT_analysis.

4. http://www.bangladesh-web.com/view.php?hidRecord=261807.

5. http://www.textiletoday.com.bd/magazine/698.

6. http://textilebulletin.com/present-situation-rmg-sectorbangladesh-2013/.

7. http://moshiur008.blogspot.com/2011/08/swot-analysiss-ofbangladesh-economy.html.

8. http://www.academia.edu/3314975/Competitive_and_Business_ Environment_analysis_of_RMG_industry_of_Bangladesh.

9. Ahmed M (2013) A Report on Readymade Garment Industries of Bangladesh p. 1-10.

10. Babu VR (2011) Industrial Engineering in Apparel Production. Wood head Publishing India Pvt Ltd p. 62-63.

11. Heizer J, Render B (2007) Operation Management. $8^{\text {th }}$ Edition, Pearson Education, Inc, pp. 354-370.

12. Ishikawa K (1986) Guide to Quality Control. Tokyo, Japan: Asian Productivity Organization, pp. 226.

13. Juran JM (1999) Juran's Quality Handbook ( $5^{\text {th }}$ Edn). McGraw-Hill, pp. AV3-AV5.

14. Porter A (2011) Operation Management. Albert Porter \& bookbon.com. p. 36-50.

15. Telsang M (2011) Industrial Engineering and Production Management $\left(13^{\text {th }}\right.$ edn), NewDehli, India. pp. 58-126.

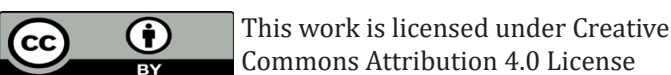

To Submit Your Article Click Here: Submit Article

DOI: $10.32474 /$ LTTFD.2018.01.000118

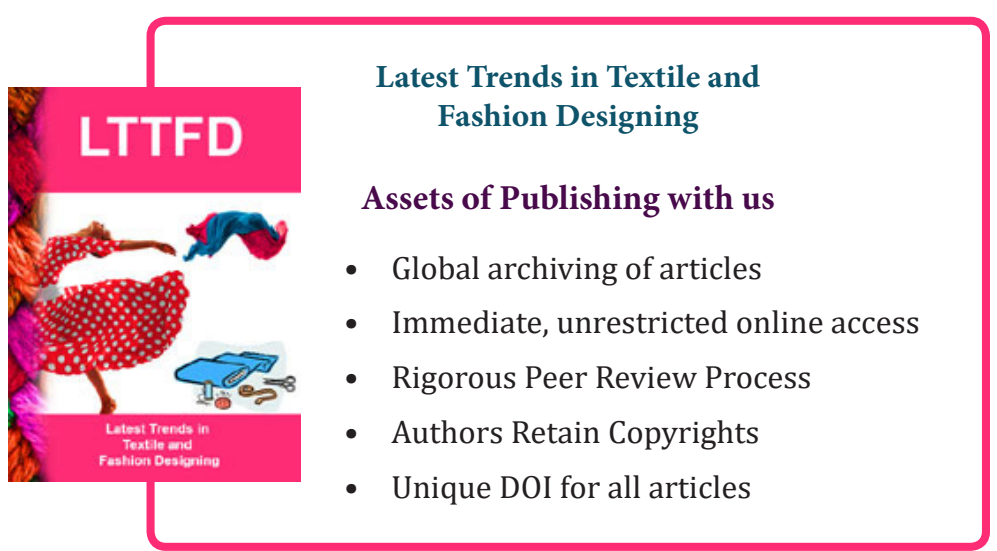

